\title{
BIMBINGAN BELAJAR TEKNIK PROBLEM SOLVING UNTUK MENINGKATKAN PENGELOLAAN DIRI DALAM BELAJAR
}

\author{
Ainur Rosidah ${ }^{1}$, Nur Faizal ${ }^{2}$ \\ Universitas Muhammadiyah Pringsewu \\ E-mail: ainurrosidah39@gmail.com ${ }^{1}$, nurfaizal@gmai.com ${ }^{2}$
}

\begin{abstract}
Student self-management in learning is a form of skill possessed of how individuals can manage and organize themselves and study time well so that the main activities or tasks that are prioritized can be realized and achieve maximum and effective goal results. The purpose of this research is to test the effectiveness of tutoring in problem-solving techniques to improve self-management in student learning. In this study using a quasi-experimental method with nonequivalent pretest-posttest control group design. As for the research, sample is the third-semester students of the guidance and counseling study program of STKIP Muhamamdiyah Pringsewu Lampung as many as 22 students. And the results of this study indicate that the tutoring of problem-solving techniques proved effective for improving selfmanagement in student learning.
\end{abstract}

Keywords: guidance learning, Problem Solving, Self Management in Learning

\section{Open Access}

\section{PENDAHULUAN}

Perguruan tinggi merupakan salah satu layanan pendidikan yang menyelenggarakan pendidikan dalam rangka mempersiapkan mahasiswa untuk memiliki kemampuan akademik dan professional dalam menerapkan dan mengembangkan serta menyebarluaskan ilmu pengetahuan, teknologi dan kesenian dalam bidangnya masing-masing sesuai dengan pengembangan pembangunan di masyarakat. Oleh karena itu, perguruan tinggi melakukan suatu kegiatan belajar mengajar yang didalamnya ada dosen dan mahasiswa.

Kegiatan belajar mengajar di perguruan tinggi dapat membangun pola pikir mahasiswa dalam memiliki ketrampilan belajar yang sesungguhnya. Artinya mahasiswa dapat belajar yang bermakna dengan mencari informasi dan menggali ilmu sendiri serta dapat menerapkan ilmu tersebut pada kehidupannya untuk dapat digunakan dalam memecahkan masalah belajar yang dialaminya. Sehingga mahasiswa dapat belajar secara optimal guna untuk dapat melaksanakan tugas belajarnya dengan maksimal dan dapat menghasilkan suatu bentuk karya atau seni yang bermanfaat bagi semua orang.

Pada kenyataannya tidak sedikit mahasiswa yang belum dapat melaksanakan tugas-tugas akademiknya dengan baik. Seperti belum mampu dalam menggunakan waktu dan suka menunda-nunda pekerjaan yang bermanfaat, karena tidak mampu 
mengatur waktu dalam mengerjakan pekerjaan belajarnya dan sering disibukkan dengan kegiatan lain untuk mencari hiburan. Hal demikian yang disebabkan karena rendahnya kemampuan pengelolaan diri mahasiswa dalam belajar, sehingga dapat berakibat pada prestasi akademik yang kurang maksimal.

Kemampuan pengelolaan diri dalam belajar merupakan suatu bentuk kegiatan dan perilaku yang harus dimiliki oleh mahasiswa, karena mahasiswa sebagai generasi penerus bangsa yang harus dibina, diarahkan, dan dibimbing untuk dapat membangun bangsa dan Negara dengan baik, sehingga harus memiliki kemampuan pengelolaan diri dengan baik terutama dalam belajarnya. Menurut Bandura (1986) menjelaskan bahwa pengelolaan diri merupakan kemampuan untuk mengatur diri atau mengendalikan diri pada pikiran, perasaan atau ucapan, dan tindakan atau perbuatan yang direncanakan dan adanya timbal balik yang disesuiakan pada pencapaian sebuah tujuan. Artinya kemampuan pengelolaan diri itu memfokuskan sebuah perhatian pada mengapa dan bagaimana seseorang berinisiatif dan mengontrol terhadap segala perilaku mereka sendiri khusunya. Karena dalam pengelolaan diri dalam belajar ada sebuah pengaturan diri dalam suatu aktivitas dengan mengikutsertakan adanya kemampuan metakognisi, motivasi, dan perilaku aktif manusia dalam melakukan semua kegiatan belajarnya. Dengan kata lain pengelolan diri dalam belajar merupakan kemampuan seseorang dalam mengelola potensi dirinya dan potensi lingkungan sekitarnya guna untuk mengatur perilaku dirinya dalam belajar.

Pengelolan diri dalam belajar artinya mendorong diri untuk dapat berkembang dan maju, serta dapat mengatur diri dan mengendalikan kemampuan untuk dapat mencapai sesuatu hal yang baik dari semua segi kehidupan agar dapat lebih baik dalam pengembangan dirinya (Gie, 2000). Sedangkan menurut Ghufron dan Risnawati (2010) pengelolaan diri dalam belajar merupakan bentuk kemampuan dalam mengatur diri individu untuk mengubah kemampuan mental dan akademik yang dimilikinya menjadi suatu aktivitas belajar yang bermanfaat dan baik.

Kemampuan pengelolan diri dalam belajar sebagai suatu bentuk untuk dapat melakukan pengelolaan waktu belajar dengan baik yang dapat membawa mahasiswa pada kesuksesan di masa mendatang. Adapun bentuk dari pengelolan diri dalam belajar berupa: strategi berfikir yang merupakan suatu strategi dalam pengambilan keputusan dilakukan dengan befikir terlebih dahulu sebelum bertindak; membuat perencanaan bagaiman menggunakan waktu belajar dalam pencapaian sebuah tujuan; dan mengaplikasikan berbagai strategi yang sudah dibuat untuk tetap dapat dilaksanakan dengan cara-cara yang sesuai dalam belajar (Levin, 2007).

Terdapat tiga faktor utama yang dapat mempengaruhi pengelolaan diri dalam belajar mahasiswa. Diantaranya adalah: faktor diri indivdu meliputi pengetahuan individu yang semakin banyak dapat membantu dalam melakukan pengelolaan, tingkat kemampuan metakognisi dan tujuan yang ingin dicapai semakin besar dapat melakukan pengelolaan diri dalam belajar dengan baik; faktor perilaku mengacu pada upaya individu dalam menggunakan kemampuan pengelolan diri dalam belajar yang berupa self abservation, self judgment, dan self reaction.

Faktor berikutnya adalah dari lingkungan yang merupakan proses individu dalam menyesuaikan diri dan rencana dalam pencapaian tujuan yang sudah ditetapkan dalam belajar, sehingga menuntut pada bagaimana lingkungan itu sendiri dapat mendukung atau tidak mendukung pada perubahan perilaku individu.

Pengelolaan diri dalam belajar dapat terjadi oleh siapa saja seperti hasil penelitian yang dilakukan oleh Hidayat (2017) menjelaskan bahwa tingkat pengelolaan diri mahasiswa dalam belajar berada pada kategori tinggi dengan nilai $72,2 \%$ dengan ditunjukkannya perilaku mahasiswa yang sering tidak mampu 
mengatur waktu belajarnya dalam hal mengerjakan tugas-tugas kuliah terlebih jika disibukkan dengan kegiatan prkatikum.

Berdasarkan observasi yang penulis lakukan pada program studi bimbingan dan konseling STKIP Muhammadiyah Pringsewu Lampung terdapat masalah pengelolaan diri mahasiswa dalam belajar berupa sulit dalam melakukan pengaturan diri atau membagi waktu belajar dengan baik karena sibuk dalam mengerjakan tugas lain dan rasa malas dalam belajar dikalangan mahasiswa. Oleh karena itu perlu adanya layanan pemberian bantuan berupa layanan bimbingan belajar dengan teknik problem solving.

Bimbingan belajar merupakan layanan bantuan yang diberikan kepada peserta didik untuk memperoleh pemahaman diri, kematangan diri dan kematangan belajar, dan memperoleh tanggung jawab dalam dirinya untuk dapat meningkatkan pengaturan waktu belajar dan kemandirian belajar (Hartono, 2002). Senada dengan pendapat Nurihsan (2011) mejelaskan bahwa bimbingan belajar yaitu bimbingan layanan yang diarahkan untuk membantu individu dalam menghadapi dan menyelesaikan masalah-masalah belajar sehingga individu tersebut memperoleh pemahaman diri, kematangan diir dalam belajar dan memperoleh pencapaian tujuan belajar yang sesungguhnya.

Layanan bimbingan belajar sebagai sebuah layanan atau pendekatan dasar dalam bimbingan dan konseling yang memberikan bentuk pemahaman diri dalam belajar yang mana mahasiswa biasanya mengalami kesulitan dalam memahami materi perkuliahan dan sulit dalam melakukan pengaturan waktu belajar, sehingga diberikan bimbingan dengan tujuan untuk dapat mengembangkan kemampuan berfikir dalam meakukan pemahaman diri dan kematangan diri serta pengelolaan diri dalam belajar dengan tepat. Karena program dalam bimbingan belajar sendiri adalah para pembimbing berupa memfasilitasi individu dalam pencapaian tujuan belajar yang diharapkan. Salah satu teknik yang dapat dilakukan dalam memberikan layanan bimbingan belajar berupa teknik pemecahan masalah atau problem solving.

Problem solving merupakan suatu bentuk proses yang diberikan dalam mencari dan menemukan sendiri solusi dari masalah-masalah yang dialami oleh individu. Menurut Suharman (2005) bahwa problem solving atau pemecahan masalah sebagai suatu bentuk proses mencari solusi atau jalan keluar dari berbagai masalah yang muncul dan dialami oleh seseorang sehingga trampil dalam menyelesaikan masalahnya sendiri tanpa bergantung pada orang lain di sekelilingnya. Tujuan dari teknik problem solving ini adalah membelajarkan bagaimana individu dapat berfikir kritis dan analitis dengan mencari berbagai bentuk strategi dalam pengambilan keputuan dengan tepat untuk pemecahan masalah yang dialaminya sendiri.

Bimbingan belajar teknik problem solving dapat efektif meningkatkan kemampuan pengelolaan diri dalam belajar, penyesuain diri dalam belajar dan kemandirian dalam belajar peserta didik. Penjelasan tersebut berdasarkan hasil penelitian Sriyono (2016) menjelaskan bahwa program bimbingan belajar efektif dapat membantu meningkatkan kemandirian belajar peserta didik pada beberapa indikator diantaranya sikap mandiri belajar sebesar 57,65\%, kesanggupan dan kebutuhan dalam belajar sebesar 45,97\%, keinginan dan cit-cita masa dean sebanyak 54,88\%, kemandirian dan kemampuan belajar sebesar 58,18\%, dan kegiatan yang menyenangkan sat belajar sebesar $57,18 \%$. Selain itu hasil penelitian yang dilakukan oleh Rosidah (2016) menyimpulkan bahwa penyesuain diri peserta didik terisolir dapat ditingkatkan dengan menggunakan teknik problem solving yang ditunjukkan dengan adanya peserta didik sudah mampu membentuk konspe pemikiran positif yang dijadikan patokan dalam membangun kemampuan penyesuain dirinya dengan baik tanpa mengalami keterisoliran bagi dirinya sendiri. 
Berdasarkan penjelasan di atas, mendorong peneliti untuk melakukan penelitian berupa bimbingan belajar teknik problem solving untuk meningkatkan pengelolaan diri dalam belajar mahasiswa di program studi bimbingan dan konseling STKIP Muhammadiyah Pringsewu Lampung.

\section{METODE}

Metode penelitian yang digunakan adalah penelitian kuantitatif dengan kuasi eksperimen "pretest-posttest non-equivalent control group design (Fraenkel \& Wallen, 1993). Artinya penelitian ini mempunyai dua kelompok yaitu kelompok eksperimen dan kelompok kontrol yang hasilnya dilakukan dengan membandingkan antara pretest dan posttest.

Populasi dalam penelitian adalah semua mahasiswa program studi bimbingan dan konseling pada semester 3 STKIP Muhammadiyah Pringsewu Lampung yang berjumlah 28 mahasiswa. untuk sampel penelitian berjumlah sebanyak 22 mahasiswa yang terindikasi memiliki masalah pengelolaan diri dalam belajar rendah yang dipilih secara random yang kemudian dibagi menjadi dua kelompok yaitu eksperimen dan kontrol.

Teknik analisis data dalam penelitian berupa analisis statistik nonparametris $X^{2}$ one sample. Dimana pada analisi data ini dilakukan untuk uji efektivitas pengelolaan diri mahasiswa dalam belajar antara kelompok ekserimen dan kelompok kontrol pada saat pretest dan postest dengan diberikan bimbingan belajar teknik problem solving.

\section{HASIL DAN PEMBAHASAN}

Hasil pengolahan data menunjukkan bahwa profil umum pengelolaan diri mahasiswa dalam belajar dapat terlihat pada table berikut ini:

\section{Tabel 1: Profil Umum pengelolaan diri mahasiswa dalam belajar}

\begin{tabular}{|c|c|c|c|}
\hline Kategori & Rentang Skor & $\mathbf{F}$ & $\%$ \\
\hline Tinggi & $91-120$ & 2 & 7,14 \\
\hline Sedang & $61-90$ & 4 & 14,28 \\
\hline Rendah & $30-60$ & 22 & 78,58 \\
\hline \multicolumn{2}{|c|}{ Jumlah } & 28 & 100 \\
\hline
\end{tabular}

Dari data diatas menjelaskan bahwa masih ada mahasiswa yang memiliki kemampuan pengelolaan diri dalam belajar rendah, sehingga apabila tidak diberikan suatu bentuk layanan bimbingan dengan baik maka akan berpengaruh pada perkembangan yang dilaluinya dalam kehidupan khususnya pada bidang belajarnya. Layanan bantuan yang diberikan kepada mahasiswa yang mempunyai kemampuan pengelolaan diri rendah berupa layanan bimbingan belajar dengan menggunakan teknik problem solving.

Peberian layanan bimbingan belajar teknik problem solving pada hasil penelitian yang dilakukan saat pretest dan postets menunjukkan adanya peningkatan kemampuan pengelolaan diri mahasiswa dalam belajar dengan melihat pada nilai rerata skor pada saat pretest dan posttest yang dilakukan. Adapaun peingkatan perolehan skor tersebut sebagai berikut: 
Tabel 2: Hasil rerata skor kemampuan pengelolaan diri mahasiswa dalam belajar

\begin{tabular}{llc}
\hline Kondisi & \multicolumn{1}{c}{ Kelompok } & Hasil Rerata \\
Pre-test & Kelompok eksperimen & 72,82 \\
& Kelompok kontrol & 70,12 \\
Post-test & Kelompok eksperimen & 109,38 \\
& Kelompok kontrol & 81,27 \\
\hline
\end{tabular}

Dari tabel diatas menunjukkan bahwa terdapat peningkatan hasil skor rerata pada kemampan pengelolaan diri mahasiswa dalam belajar saat dilakukan pretest dan posttest baik pada kelompok eksperimen ataupun pada kelompok kontrol tersebut.

Selanjutnya pengujian efektivitas bimbingan belajar teknik problem solving untuk meningkatkan pengelolaan diri mahasiswa dalam belajar pada penelitian ini menggunakan analisis data berupa uji beda yaitu uji statistik nonparametris $X^{2}$ one sample. Adapun bentuk hasil analisis datanya tersedia pada tebel berikut:

Tabel 3: Hasil Uji Statistik

\begin{tabular}{llrrr}
\hline & & \multicolumn{2}{c}{ Mean Rank } & Sum of Ranks \\
\hline Eksperimen-Kontrol & Negative Ranks & $0^{\mathrm{a}}$ & .00 & .00 \\
& Positive Ranks & $11^{\mathrm{b}}$ & 7.02 & 83.00 \\
& Ties & $0^{\mathrm{c}}$ & & \\
& Total & 11 & & \\
\hline
\end{tabular}

Dari hasil pengujian diatas menjelaskan bahwa hasil skor kemampuan pengelolaan diri mahasiswa dalam belajar mengalami peningkatan yang sangat signifika. Hal tersebut terlihat pada signifikansi $<a(0,001<0,05)$, yaitu Ho ditolak dan Ha diterima. Artinya bimbingan belajar teknik problem solving efektif untuk meningkatkan pengelolaan diri mahasiswa dalam belajar.

Hal tersebut sesuai dengan pendapat Dejanasz (2002) bahwa pengelolaan diri dalam belajar atau juga sering disebut dengan pengaturan diri dalam belajar merupakan suatu bentuk kerampilan dalam mengelola diri dan mengelola waktu belajar berdasarkan pada prioritas utama untuk mencapai sebuah tujuan dengan memperkirakan waktu yang efektif dalam belajar, membuat jadwal belajar, serta mengorganisasikan diri dan waktu belajar dengan efektif, yaitu dengan terus melakukan bimbingan belajar dengan pemberian pemecahan masalah atau problem solving pada diri sendiri. Sehingga hasil yang diperoleh maksimal tanpa adanya kendala ataupun masalah pengelolaan diri dalam belajar mahasiswa.

\section{SIMPULAN}

Berdasarkan hasil pengujian uji statistik nonparametris $X^{2}$ one sample diperoleh kesimpulan bahwa bimbingan belajar teknik problem solving efektif untuk meningkatkan pengelolaan diri mahasiswa dalam belajar semester 3 program studi bimbingan dan konseling STKIP Muhamamdiyah Pringsewu Lampung dan dengan dibuktikan adanya perbedaan rerata antara kelompok eksperimen dan u kelompok kontrol pada saat pretest dan postest. 


\section{DAFTAR PUSTAKA}

Bandura, A. (1986). Social Foundations Of Thought And Action: Asocial cognitive theory. Egelwood cliffs, NJ: Prentice Hall.

Dejanasz, S. (2002). Interpersonal Skill In Organization. Boston: Mc-Graw Hill.

Fraenkel,J.R. and Wallen, N.E. (1993). Second Edition. How to Design and Evaluate Research in Education. Singapore: Mc-Graw Hill International.

Ghufron, Nur. dan Risnawati, Rini. (2010). Teori-Teori Psikologi. Jogjakarta: Ar-Ruzz Media.

Gie, The Liang. (2000). Cara Belajar yang Baik bagi Mahasiswa edisi kedua.Yogyakarta: Gadjah Mada University Press.

Hidayat, Muhammad Yusuf. (2017). Pengaruh Kemmapuan Mengelola Diri Terhdap Kedisiplinan Belajar Dan Kreativitas Berfikir Mahasiswa. Jurnal Auladuna Pendidikan Dasar Islam, Vol.4, No.1, Hlm 30-39.

Hartono, B Agung dan Sunarto. (2002). Perkembangan Peserta Didik. Jakarta : Rineka Cipta.

Levin, Peter. (2007). Skilful Time Management. London: Open University Press.

Nurihsan, Achmad Juntika. (2011). Bimbingan Dan Konseling Dalam Berbagai Latar Kehidupan. Bandung: Refika Aditama.

Rosidah, Ainur. (2016). Bimbinga Kelompok Melalui Teknik Problem Solving Untuk Meningkatkan Penyesuaian Diri Siswa Terisolir. Jurnal Fokus Konseling, Vol.2, No.2, Hlm 136-143.

Sriyono, Heru. (2016). Program Bimbingan Belajar Untuk Membantu Meningkatkan Kemandirian Belajar. Jurnal Sosio-E-Kons, Vol.8, No.2, Hlm 118-131. 